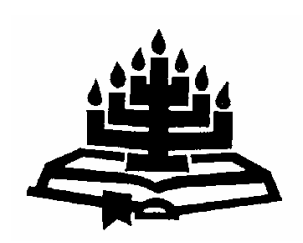

\title{
Heinrich Bullinger, political covenantalism and Vermigli's commentary on Judges
}

\author{
Andries Raath \\ Department of Constitutional Law and Philosophy of Law \\ University of the Free State \\ BLOEMFONTEIN \\ E-mail: raathA.RD@mail.uovs.ac.za
}

\begin{abstract}
Heinrich Bullinger, political covenantalism and Vermigli's commentary on Judges

The Zurich political federalists under the leadership of Heinrich Bullinger had a number of important views in common: firstly, they subscribed to the ideal of the covenanted nation under God; secondly, they maintained the view that magistrates and their subjects have a covenantal calling to live according to God's law; thirdly, the binding together (consolidation) of the covenanted Christian polity by means of the oath; fourthly, the right to resistance when the conditions of the covenant are broken; fifthly, the offices of magistrates and pastors are mutually to assist one another in maintaining and furthering the conditions and requirements of the Biblical covenant in the consolidated Christian community. Vermigli used these principles, together with the Chrysostomian and Lutheran views on magisterial office, to develop an influential theory of theologico-political federalism in the Reformational tradition.
\end{abstract}

\section{Opsomming}

Heinrich Bullinger, politieke verbondsluiting en Vermigli se kommentaar op die boek Rigters

Die politieke federaliste onder die leierskap van Heinrich Bullinger het 'n aantal belangrike gesigspunte in gemeen gehad: eerstens het hulle die ideaal van die nasie as 'n saamgebinde verbondseenheid onderskryf; tweedens het hulle die perspektief gehandhaaf dat burgerlike owerhede en hul onderdane 'n verbondsroeping het om in ooreenstemming met God se wet te leef; derdens die samebinding (konsolidasie) van 
die verbondsgebaseerde Christelike gemeenskap deur middel van die eed; vierdens die reg van verset in die geval waar die voorwaardes en vereistes van die verbond verbreek word; vyfdens dat die ampte van die burgerlike owerhede en predikers mekaar wedersyds moet ondersteun in die handhawing en bevordering van die voorwaardes en vereistes van die Bybelse verbond in die gekonsolideerde Christelike gemeenskap. Vermigli het dié beginsels, tesame met die standpunte van Chrysostomus en Luther oor die amp van die burgerlike owerheid, gebruik om 'n invloedryke teorie van teopolitiese federalisme in die Reformatoriese tradisie te ontwikkel.

\section{Introduction}

The idea of the consolidated Christian community under the governance and co-operation of the political and ecclesiastical authorities reached its zenith in Zurich towards the middle of the second part of the 16th century. Huldreich Zwingli, the leader of the Zurich Reformation, and his successor, Heinrich Bullinger, committed themselves to establish Zurich as the Respublica Christiana under the political authority of the Christian magistrate. The idea of the consolidated Respublica Christiana flowed from their understanding, interpretation and application of the covenant between God and his people. The Zurich Reformers strove to establish a Christian community bound together by the covenant and its conditions enforced on the whole of the community. The duty of the pastors was to proclaim these conditions to the people, including the magistrates, and the latter, as God's servants, were to implement these (Baker, 1980). From the 16th century Zurich emanated the legacy that exposed an unique perspective concerning the relationship between God and man in the political sphere. This legacy provided Vermigli, Ponet, Goodman, Languet, Knox, Hooper and others with an alternative theologico-political paradigm (De Freitas, 2003). Central to this legacy is the idea of the Biblical covenant which denotes a unique, biblically-based relationship between God and man - a relationship that was expressly put forward by Bullinger (Bullinger, 1534 as quoted in McCoy \& Baker, 1991). According to Bullinger, the term covenant means a bilateral, mutual and conditional agreement between God and man (Baker, 1980:13-17). This agreement includes not only God's promises, but also certain conditions that man is obligated to meet (Baker, 1980:xxii). For Bullinger, then, the covenant served as the foundation for social and political policy and law among Christian people and thus, as the framework for his socio-political theory - the covenant being the cement that unified God's people in the Christian 
community (Baker, 1980:136-137). Bullinger became the first Reformer to postulate an explicit covenant theology accompanied by a covenantal political theory of the covenantal commonwealth (Raath \& De Freitas, 2001:286). Bullinger's theology was based on a single covenant, which, in turn, implied other sub-covenant structures within a political paradigm, such as between the supreme magistrate and the people (cf. Baker, 1980:176). A nation in covenant with God and the government, is there to facilitate the required conditions of the covenant. God's people needed the magistrate and his laws to govern every aspect of life. The Christian magistrate was sovereign in Christian societies, and it was his duty to enforce the conditions of the covenant. The covenant was therefore the cornerstone of the Christian state (McCoy \& Baker, 1991:26-27). The commonwealth of Zurich had the same covenanted relationship with God as Israel under Moses or Joshua, with the Christian commonwealth of Zurich viewed as the "new Israel" (Baker, 1980:163).

Bullinger had extensive correspondence with theologians and political theorists in Europe, Scotland and England. Therefore the contact of scholars from Britain and Europe with the Zurich divines, as well as the direct contact Bullinger had with the Marian exiles visiting Zurich as well as visitors from elsewhere in the course of the 16th century, established a network of correspondents and acquaintances. That contributed largely to the establishment and development of a distinct theologico-politcal approach to politics, espousing the idea of federalism in politics and based it on the idea of bilateral covenanting in the Christian polity. Among the members of the Zurich circle of theologico-politcal federalists, Martyr Vermigli was one of the pioneers to fuse Chrysostome's and Luther's ideas on magisterial office with the notion of theologico-political federalism. In a fundamental respect, Vermigli applied the idea of the Biblical covenant to political theory, thereby making him a pioneer in the field of Reformed political contractarianism.

\section{Heinrich Bullinger, political covenantalism and Vermigli's commentary on Judges}

The year 1549 witnessed two important events which would have had an important effect upon Vermigli's political thought. In this year rebellion in England became a reality with the introduction of the new English Prayer Book (Anderson, 1978:160). In March of the same year a work by Bullinger appeared under the title Sermonum Decades duae. De potissimis uerae religionis capitibus, quorú 
catalogi uersa fragella exhitebit. This work (The Decades) was destined to contribute in two major respects to the subsequent development of a systematical analysis of the theoretical underpinnings of magisterial office and the nature and role of civil magistracy in the Christian commonwealth.

In the sixth sermon of Decade Two, Bullinger raised the question of whether an evil magistrate, a tyrant, is of God or not. ${ }^{1}$ Bullinger expressed virtually the same view that he had maintained in his commentary on Romans (1532). Subjects vexed by tyrants must first reform their religious manners, then they must pray that God will save his people from mischief, and finally they must not resist the office ordained by God (Bullinger, 1849-1852:II:316-17 [II:6]). In this Decade, Bullinger did, however, leave room for resistance to tyranny in so far as God "(s)ometimes ... stirreth up noble captains and valiant men to displace tyrants, and set God's people at liberty; so as we see many examples there of in the books of Judges and Kings" (Bullinger, 1849-1852:II:318 [II:6]; Anderson, 1957:163). Bullinger added:

But lest any man do fall to abuse these examples, let him consider their calling by God: which calling if he have not, or else do prevent, he is so far from doing good in killing the tyrant, that it is to be feared lest he do make the evil double so much as it was before (Bullinger, 1849-1852:II:318 [II:6]; Anderson, 1957:163).

Bullinger's references to Judges and Kings must be read close together with the second important aspect contained in the Decades, namely the oath-making preceding the institution of kings and magistrates and the vow-like nature of their covenant with their subjects. ${ }^{2}$ The discussion of the nature and role of oaths precedes

1 The text used here is Bullinger, 1849-1852 (see Decade 2, sermon 6 [II:6]). At 314 Bullinger answers as follows: "To this I answer, that God is the author of good, and not of evil. For God by nature is good, and all his purposes are good, being directed to the health and preservation, not to the destruction; of us men. Therefore the good and healthful ordaining of the magistrate, without all doubt, is of God himself, who is the author of all goodness."

2 In [1516] 1997 Erasmus, in his Education of a Christian Prince (p. 17, note 29), had already espoused the idea that it is only if the people have explicitly sworn allegiance to their prince that he has the right to rule over them: "Only if they believe that he will behave towards them 'like a father' (i.e., in their 'family' interests, not his own) will they thus swear. It is the oath of allegiance, not the badges of office, which confers entitlement to rule." Luther also, in the early stages of the Reformation, expressed himself favourably on the principle of oathswearing by kings and subjects. Alluding to the second commandment, Luther states that those who swear true oaths to the government honour God's name 
his exposition of magistracy and is also contained in Decade Two. ${ }^{3}$ Bullinger starts his discussion of oaths referring to Matthew 5:33, 34. The key perspective in Bullinger's commentary is contained in his observation that solemn oaths are both profitable and needful. The law of God and words of Christ do not forbid things profitable and needful, and therefore they do not condemn solemn and lawful oaths (Decades II:244, 245 [II:3]).4 Bullinger (Decades II:245

and adorn the truth: "The oath of those who swear thoughtfully and do not defend the truth is beyond what is required and evil; but where the oath serves the truth and is useful for preserving goodwill and concord, there proper swearing does not abuse Gods name but gives it honour, namely, that God may be feared and peace and quiet remain" (Luther's Works (LW) 1956. Vol. 4:78; also note his comments on p. $83 \mathrm{ff}$. and p. 86-88; see Luther's remarks on the principle of God binding himself by way of oath on p. 142-144; 146-148 and $150 \mathrm{ff}$.). In his notes on Ecclesiastes (Vol. XV:135), Luther interprets Ecclesiastes 8:2-3 to mean that man must obey political institutions because God wants us to be bound by the word and to obey it. Whatever the magistrate commends in accordance with the laws, that must be done. The reference to the oath of God in this passage, to Luther, does not mean the oath by which God swears, but that which one swears to God to obey the ruler, ultimately entailing that political obedience is included in obedience to God. In 1525 Luther, in his attack on the "Robbing and Murdering Hordes of Peasants", arraigned the peasants because they had violated their oaths of loyalty to their rulers and were subject to temporal punishment (Vol. 46: The Christian in Society III, 48; also see p. 113). However, it was Heinrich Bullinger who combined the principle of oath-making and political obedience with the Biblical covenant. (For a most illuminating discussion of oath-taking and socio-political covenanting in pre-Reformation thought, see Lillback (2001:2957).)

3 Bullinger's discussion of oaths under the third precept of the Ten Commandments includes an elaborate discussion of the lawfulness of swearing; for what causes we ought to swear; what an oath is; how we ought to swear; oaths as the special honour done to God; the conditions of holy oaths; whether wicked oaths must be performed; it is best to break an ill oath; how religiously we ought to keep our oaths; large rewards promised to those who keep their oaths, etcetera. His views on these issues closely resemble the perspectives of his predecessor Huldreich Zwingli (1484-1531), who, as early as 1523, in his debates with the Anabaptists, took the oath to be a constitutive element to the powers exercised by political authorities. Addressing the Catabaptists, in his Refutation of Baptist Tricks, Zwingli states that if the oath in any state is given up "according to the catabaptists' desire" the magistracy would be removed and all things follow as they would have them (Zwingli, 1901). Elsewhere (p. 210) Zwingli writes that an "oath is ... a divine thing, a sacred anchor to which we flee when human wisdom can go no farther" (also see p. 212-214). Also for Zwingli the oath is closely attached to the covenant: "An oath is a religious matter; he who makes oath binds himself to the sum of religion" (p. 214). It is also noteworthy that Zwingli in this treatise deals with oaths in the second part (p. 177-219), before he enters into a discussion of the Biblical covenant in part three (p. 219-251).

4 At 245 Bullinger states: "An oath therefore in the law of Christ is not forbidden; and it is lawful for a Christian man both to exact and also to take an oath." 
[II; 3]) goes further to add that a man is not worthy to be called a Christian if he refuses to swear lawfully.

Bullinger also warns against the practice in many countries where magistrates require oaths as an "usual and received custom", to take oaths on light occasions: "Let magistrates therefore learn and know, that an oath ought not to be required but in earnest affairs: as when it standeth for the glory of God, for the safety of our neighbour, and for the public weal" (Decades II:246 [II:3]). To Bullinger magistrates ought to apply the use of oaths reverently (Decades II:246 [II:3]). Addressing the political authorities, Bullinger warns against perjury: "But woe to the people's princes, if through their wicked negligence an oath be not esteemed! For he, without doubt, will punish them sharply for it, who saith: 'Because I will not suffer him to go unpunished that taketh the Lord's name in vain'" (Decades II:246 [II:3]). Oaths, being the calling on or taking to witness of God's name to confirm the truth of that we say, place us in danger of God's wrath and vengeance, "unless we do truly and indeed both speak and do the thing that we promised" (Decades II:247 [II:3]). ${ }^{5}$ The conditions pertaining to oath-taking are fourfold: firstly, we ought to swear by the living God; secondly, man should swear in truth; thirdly, man should swear with great discretion; and fourthly, man should swear in justice or righteousness, so that oaths do not tend against the love of God and our neighbour (Decades II:249 [II:3]). Bullinger's answer to the question of whether wicked oaths may be performed, is brief and to the point: if any man swears against faith and charity, so that the keeping of his oath may tend to the worse, then it is better for him to change his oath than to fulfil it (Decades II: 250 [II:3]). Lastly Bullinger states that if we love God, if we desire to sanctify his name, "if we take the true God, and for our God", if we wish him to be gentle and merciful towards us, and to be our present "deliverer and aider" in everything, then man must exercise diligent care to swear with fear devoutly, "and holily to keep and perform the oath that we devoutly make."6

Because the making of covenants is squarely based on promises of a vow-like nature to keep one's obligations, Bullinger's discussion of oaths precedes his analysis of covenants. Later in his Decades

5 It, therefore, "is manifest that the faithful must swear by the only eternal and most high God ..."

6 Decades II:II:252 [II:3]: "But unless we do this, then terrible threatenings and sharp revengement of God's just judgment are thundered from heaven against us transgressors." 
Three Bullinger deals with covenants (Decades II:III:169 et seq. [III:6]). ${ }^{7}$ God's covenant with man has two conditions: the first declares what God promises and will do for his confederates; the second comprehends the duty of man, "which he doth owe to God, his confederate and sovereign prince" (Decades II:170 [III:6]). In Genesis 17:1 God demands of man to do His will and to be upright. That "uprightness is gotten by faith, hope, and charity; in which three are contained all the offices of saints, which are the friends and confederates of the Lord" (Decades II:171 [III:6]).

The close personal relationship between Bullinger and Vermigli is reflected in their correspondence, which totalled forty-three letters covering the period from 5 October 1542 to August 1562 (Anderson, 1973:41-64). From this correspondence it appears that Vermigli and Bullinger were of "particular importance" to each other in spite of the fact that Bullinger survived Vermigli by thirteen years (Anderson, 1973:42). Not only did Bullinger congratulate Vermigli on the results of the 1549 Oxford debates on the Eucharist (Anderson, 1973:43), but Vermigli attributed his views on the Eucharist to Bullinger's influence (Anderson, 1973:44). Vermigli praised Bullinger's sermons or Decades which were "favorably received" (Anderson, 1973:45, 47 ) and urged him to assist the publication of his commentary on 1 Corinthians in Zurich (Anderson, 1973:45). Early in 1551 Vermigli received two letters from Bullinger, recommending Vermigli's commentary to the printer in Zurich and selecting a proof reader (Anderson, 1973:46). In October 1551 Vermigli was so encouraged by Bullinger's response to his Corinthians commentary, that he turned towards the preparation of his commentary on Romans (Anderson, 1973:46). The over-all impression gained from their correspondence is that these two influential reformers not only cultivated a strong personal friendship, but also maintained and promoted a strong working relationship. This friendship greatly influenced Vermigli's views on the covenant and other theological matters.

During his second sojourn at Strasbourg from 1553 to 1556, Vermigli absorbed, integrated and applied Bullinger's perspectives on the importance of the books Kings and Judges to civil magistracy and his comments on oaths, vows and covenants and their application to practical political issues. 8 The integration of oath-

7 For Bullinger's definition of covenants, see Baker (1980, xxi-xxii).

8 Martin Bucer's application of the idea of covenantalism to practical political issues in the line of Bullinger's work, would also have influenced Vermigli's political theology in fundamental respects. This work of Bucer (On the Kingdom of Christ) 
making with the office of magistracy in Vermigli's commentary, accompanied his interest in the idea of the Biblical covenant. Upon his arrival at Strasbourg, Vermigli began lecturing on the Book of Judges. Here he experienced much pressure from a Lutheran faction under Johann Marbach (1521-1581), demanding him to sign the Wittenberg concordat of 1536 as a declaration of good faith (McLelland, 1994:11). Vermigli's commentary on Judges reflects a substantial line of consistency in his treatment of magisterial office, largely following the same line as his commentary on Romans. However, in this commentary the theme of the covenant enters into his interpretation of Judges (Vermigli, 1564, chapter 2). Vermigli reflects on the acceptance of the idea of a bilateral covenant in the line of the Zurich Reformation: God by covenant had prescribed two things in particular: firstly, that the Israelites should make no league with the Canaanites; secondly, that they should destroy their altars and temples (Vermigli, 1564: fol. 60). The Israelites, in not meeting the conditions of God's covenant, transgressed the law. Although they had not yet fallen into idolatry, they were reproved for violating the covenant by saving the altars of the Canaanites. God therefore refrains from meeting his covenantal promises: "I will not expell the Chananites out of this region as I had promised" (Vermigli, 1564: fol. 78). God requires of his people to walk in his commandments. God furthermore affirmed to Abraham that he himself would be his reward, showing that in the covenant not only carnal and earthly good things were promised: "Undoubtedly it were a great shame euen for Kings and Princes, which being compared with God are but fleshe and bloud, if they provide for their Citizens outwarde commoditeyes, quietnesse and peace namely that they might liue happily and virtuous liye. Wherefore if Princes seeke for goodes of the minde for their Citizens, is it not meete that God hymsellfe prouided farre more noble thinges for the publique wealthe of the Isrealites whiche he faythfully gouerned (Vermigli, 1564: fol. 75). God complains to the Hebrews that they had broken the covenant which he had made with their fathers. For they were departed from "the true fayth and inward godlynesse" (Vermigli, 1564: fol. 75). The

was written in 1550 for the young English king Edward VI, the son and successor of Henry VIII, in the hope that during his reign and under his auspices, the Reformation would be established in England "in such a way that it would shape and penetrate the entire life of the nation" (Pauck, MCMLXIX:157). In the same year Bucer wrote to Sir John Cheke, sending him a copy of his De Regno Christi constituendo; signifying that he had shown it to none other but $\mathrm{P}$. Martyr (then teaching at Oxford), who, according to Bucer, shared the same opinion (p. 159). In this work Bucer explicitly refers to the oaths required of magistrates by Justinian (p. 364-365) after having stated the acceptance and reverence for the Lord's covenant as a fundamental element in the reformation of society (p. 266). 
root of their covenant-breaking was their sin in not believing in God. This "league" of the Hebrews with God not only bound themselves, but also their posterity.

Following Bullinger, Vermigli accepts that promises or oaths form the basis of the covenant. Vermigli distinguishes between oaths, as lawyers do, between those of an approving or affirming nature and others of a promissory nature: "For whé we swere, either we do affirme or els deny some thing to be or to haue ben, which we ought neuer to do with euil guile, if we adde therunto an othe. Or els we promise to performe something ... for as much as faith is to be kept eué with our enemy" (Vermigli, 1564: fol. 85 b). If an oath is made, "guile is not to be used unless peradventure the one partye to whom the othe is made, shall go from the conditions and couenantes, for then the common saying must take place, he that breaketh faith, let faith also be broké unto him" (Vermigli, 1564: fol. 86 a).

Commitments made by means of oaths or vows are to be kept. If men are received into any office and according to the custom are compelled to swear to observe laws, statutes and decrees, they are required to observe things unless they find any of these against the word of God (Vermigli, 1564, fol. 86 b).

\section{Covenant and magistracy in Vermigli's commentaries on Samuel and Kings}

Vermigli moved to Zurich in 1556 where he began lecturing on 1 Samuel in August 1556 and soon thereafter on Kings. Martyr's commentaries on these two books, however, started much earlier. On 4 October 1562, Vermigli told Cox that he was wholly devoting himself to his commentaries on Samuel and Kings (Anderson, 1978:189). Kings followed Samuel in Vermigli's trilogy of commentaries, states Anderson, perhaps for the reason that Vermigli owned a copy of Vergerio's 1555 Strasbourg edition of Reginald Pole's De Unitate which contained excerpts from political statements by Calvin, Bucer, Brenz and Melanchthon (Anderson, 1978:192). In his De Unitate Pole used examples from 1 Samuel 8:7 and 1 Kings 8 where the Hebrews consulted a priest before they made a king. Anderson concludes that a direct reference to Pole's De Unitate on folio 106 of Melachim (1556) convinces one that Pole's treatise republished in 1555 and his selection by Queen Mary as Cranmer's successor to Canterbury, lie behind Vermigli's choice of all three commentaries as suitable, necessary and timely lectures for the Marian exiles. To Anderson the political comments in 
Vermigli's Judges, Samuel and Kings form a triple response to the Cardinal of England (Anderson, 1978:192).

It is important to note that Vermigli's commentary on Kings is one of the last works he prepared and that his comments on Kings reflect his more mature views on covenant and magistracy and the integration of Bullinger's perspectives on oaths and vows to the office of magistrates. Relying on Bullinger's direct reference to historical examples from the Old Testament slaying of tyrants, Vermigli refined the idea of political covenantalism - a concept which had an impact of magisterial proportions in subsequent political developments in the field of Reformed and liberal constitutionalism. Although Anderson, in his seminal work on Vermigli's political theory, identified some of the dynamics which could have impacted on the sequence of Vermigli's writings on politics, the integration and refinement of Bullinger's covenantal views appear to be the most probable in the light of the general development of Vermigli's political thought. 9

Vermigli's views on political covenantalism in Part Four of his Commonplaces (1583) are embedded in the framework of his political theory expounded in his commentaries on Romans and Judges. His starting point is the sovereignty of God's Word: "Happie is that Commonweale or Church which is ruled and gouerned by the word of God: And contraiwise unhappie is the same, which followeth the inuentions of men, reiecting the Oracles of God" (Vermigli, 1583: fol. 323a). The principles pertaining to magisterial office and obedience by subjects are formulated by Vermigli along the same lines as those in the Romans and Judges commentaries. Because the magistrate is a living law and because he represents God, they who rise against him are justly said to be seditious (Vermigli, 1583: fol. 323b). Because the magistrate must be reverenced, subjects must not be against him, so long as he rules according to the word of God, "or by honest ciuill decrees ..." (Vermigli, 1583: fol. 323b). If, however, the magistrate commands ungodly things and those things which are repugnant to the Word of God, he is not to be heard and neither must he be obeyed, for we must obey God rather than men (Vermigli, 1583:324a). If the magistrate commands us to worship images, to corrupt the sacraments, to follow dishonest customs, or if

9 Skinner ([1978] 2000:213) observes that Vermigli, in his Commentary upon the Book of Judges, appears to withdraw much of what he had earlier allowed in his commentary on Romans (vgl. Vermigli, 1568). This must be appreciated against the background of his development from the Chrysostomian-Lutheran perspectives on political authority to his cultivation of the political covenant, due to Bullinger's influence. 
he sets new articles of faith, he must not be obeyed. The crime of sedition cannot be laid against subjects in such cases (Vermigli, 1583:324a). The commandment that no man should speak evil of the prince of his own nation, is violated when that is done rashly, or for one's own advantage; "or else when the authority it selfe is contemned" (Vermigli, 1583:324a).

Considering the issue of political resistance, Vermigli's originality in refining and applying political covenantalism becomes manifest. Attending to the question of whether it is lawful for subjects to rise against their prince, Vermigli divides subjects into two categories: some are merely private men and others, although inferior, are in such a position that the superior powers are dependant upon them. Firstly, those which only are subject and counted altogether private, ought not to rise against their princes and lords and displace them of their dignity or degree. Because the sword is given to the powers, they who resist the power are said to resist the ordinance of God (Vermigli, 1583:324b). Secondly, there are others in the commonwealth, which in place and dignity, are inferior to princes and yet in deed do not elect the superior power and by certain laws govern the commonwealth, as done by the electors of the empire. If the prince does not perform his covenants and promises, it is undoubtedly lawful for these to bring the prince into order and to constrain him and even by force to compel him to perform the conditions and covenants which he had promised, "and that by warre when it cannot otherwise be done" (Vermigli, 1583:324b). In support of this principle, Vermigli cites examples from the history of the Romans who sometimes compelled the consul, whom they themselves had created, to vacate his office; the Danes who deposed their king and held him in prison; the English who sometimes compelled their kings to render account of the money which they had misspent; Tarquinius the Proud who was thrown out of his kingdom by the Romans because of his cruelty and arrogance; Brutus and Cassius who slew Caesar, and so on (Vermigli, 1583:324b). Applying these principles to the issue of whether Jehoiada did right in putting Athalia from the kingdom, Vermigli finds several reasons why Jehoiada did lawfully conspire against Athalia: he was not altogether a private man, but was the high priest in the commonwealth, unto whom belonged the power to judge not only ecclesiastical and sacred, but also civil causes. It was meant that the commonwealth or kingdom of Juda should be delivered from this woman's tyranny. Also the law of Deuteronomy was to be observed, namely that the kingdom should not fall to strangers (Vermigli, 1583:325b). The underlying motive in Vermigli's 
trilogy of Judges, Samuel and Kings, and his views on political covenantalism in his Commonplaces are solidly based on the Biblical covenant.

\section{Conclusion}

Peter Martyr Vermigli should receive the credit for his pioneering efforts in applying the principles of Biblical covenantalism to the idea of resistance to tyranny. Moving from the Chrysostomian-Lutheran views on the enforcement of political authority and obedience to magisterial authorities, Vermigli became the pioneer in conceiving the idea of the political covenant and its implications for Reformed theories of resistance to tyranny. A host of Reformation authors soon followed the line of theologico-political resistance to tyranny pioneered by Bullinger. In 1554 Beza published his De haericis a civile magistrate puniendis, in which he relied on Bullinger (The Decades, sermons $7 \& 8$ ) in fundamental respects. Beza conclude that if princes combat the reign of Christ, either through apparent cruelty or through gross ignorance, the church should first of all take refuge in prayers and tears, and correct its life, "(f)or these are the arms of the faithful for overcoming the rages of the world". However, the inferior magistrate, according to Beza, must with prudence and moderation, "yet constantly and wisely", maintain pure religion in the area under his authority." 10

Vermigli's commentaries on the Old Testament books of Samuel, Kings and Judges, introduced an idea of magisterial proportions into early Reformational and Renaissance political theory, making political covenantalism the dominating political paradigm - the basis of political legitimacy and federal legality in Reformation thought. The question of whether Vermigli showed substantial originality in his political views, must be answered both positively and negatively: on the one hand he drew heavily from the political theology of Chrysostom, Luther and Bullinger in the development of his thought and can therefore not be regarded as being "original" in postulating and developing the idea of magisterial office. On the other hand he was "original" in the sense of applying the theology of oath-making and covenantalism to the sphere of politics, thereby stating the basis of political covenantalism - perhaps the most influential concept in practical Reformed politics for the following two centuries.

10 DE HAERETICIS ACI / uili Magistratu puniendis / Libellus, ad- / uersus Martini Belli farrginem, \& no / uerum Academicorum sectam. / Theodoro Beza Vezelio auctore. / Oliuia Roberti Stephani. / M.D.LIIII, 133. See his references to Bullinger at 296, 209. Also note the commentary by Kingdon (1955: 88-100). 
Martyr Vermigli's refinement of the idea of the political covenant and its application to the office of magistracy, represents the highest level of development of Reformed politics in the sixteenth century. Not only did his refinement of theologico-political federalism exert substantial influence in Europe (through Hotman and Mornay), but also in Scotland (through Knox, Buchanan and Rutherford) and in England (Milton). In all the Reformed traditions the idea of the covenant shaped political thought in profound respects. The principle of resistance to tyranny, already identified by Zwingli and Bullinger, found a strong anchorage in covenant theology. In a certain sense Vermigli's commentaries on political covenantalism in Scripture impacted substantially on Reformed politics in the sixteenth and seventeenth centuries and brought the development theologico-political federalism to its logical conclusion.

\section{List of references}

ANDERSON, M.W. 1957. Peter Martyr: A Reformer in exile (1542-1562). A chronology of Biblical writings in England and Europe. Nieuwkoop: De Graaf.

ANDERSON, M.W. 1973. Peter Martyr, Reformed theologian (1542-1562). His letters to Heinrich Bullinger and John Calvin. Sixteenth Century Journal, 4: 41-64.

ANDERSON, M.W. 1978. Royal idoltary: Peter Martyr and the Reformed tradition. (In Hillerbrand, Hans J., ed. Archiv für Reformationsgeschichte. p. 157-200.)

BAKER, J.W. 1980. Heinrich Bullinger and the covenant: The other Reformed tradition. Ohio: Ohio University Press.

BULLINGER, H. 1849-1852. The Decades. (4 vols.) ed. for the Parker Society. Cambridge: Cambridge University Press.

DE FREITAS, S. 2003. Samuel Rutherford on law and covenant. The impact of theologico-political federalism on constitutional theory. Bloemfontein: University of the Free State. (Unpublished masters thesis in Law.)

ERASMUS, D. [1516] 1997. The education of a Christian prince. (Transl. \& ed. by Lisa Jardine). Cambridge: Cambridge University Press.

KINGDON, R.M. 1955. The first expression of Theodore Beza's Political Ideas. (In Hillerbrand, Hans J., ed. Archiv für Reformationsgeschichte. p. 88-100.

LILLBACK, P.A. 2001. The binding of God: Calvin's role in the development of covenant theology. Grand Rapids: Baker Academic.

LUTHER, M. 1956. Luther's Works (LW). Vol. 1, 2, 4-7, 13. (Jaroslav Pelikan, ed.) Saint Louis, Missouri: Concordia Publishing House. (Ages Digital Library Collection: Books for the Ages, Version 1.0, 1997.)

McCOY, CHARLES S. \& BAKER, J. WAYNE. 1991. Fountainhead of federalism: Heinrich Bullinger and the covenantal tradition, with a translation of the De testamento seu foedere Dei unico et aeterno, 1534 by Heinrich Bullinger. Louisville: John Knox.

McLELLAND, JOSEPH C., ed. 1994. The Peter Martyr Library. Volume 1: Early Writings. Kirksville: Sixteenth Century Publishers. 
RAATH, A.W.G. \& DE FREITAS, S. 2001. Theologico-politcal federalism: The office of magistracy and the legacy of Heinrich Bullinger (1504-1575). Westminster Theological Journal, 63: 285-304.

SKINNER, Q. [1978] 2000. The foundations of modern political thought. Vol. 2: The Age of Reformation. Cambridge: Cambridge University Press.

VERMIGLI, P.M. 1564. Most fruitfull of learned commentaries. London: Day.

VERMIGLI, P.M. 1568. Most learned and fruitfull commentaries upon the Epistle of St. Paul to the Romanes. London: Daye.

VERMIGLI, P.M. 1583. The common places of the most famous and renowned diuine doctor, Peter Martyr. Diuided into foure principall parts: With a large addition of manie theologicall and necessarie discourses, some neuer extant before. (Transl. Anthonie Marten.) London: Denham \& Middleton.

ZWINGLI, H. 1901. Selected works. (Ed. by Samuel Macauley Jackson.) Philadelphia: University of Pennsylvania.

\title{
Key-concepts:
}

\author{
Bullinger \\ Chrysostom \\ covenant11 \\ Federalism \\ Luther \\ theologico-political federalism \\ Vermigli
}

\section{Kernbegrippe:}

\section{Bullinger}

Chrysostomus

Federalisme

Luther

teo-politiese federalisme

verbond12

Vermigli

11 The term covenant is used here to express the conditional, mutual and reciprocal relationship between God and man, and which encompasses the political substructures in the Christian commonwealth.

12 Met verbond word bedoel die voorwaardelike en wedersydse verhouding tussen God en die mens en wat as sodanig die politieke substrukture in die Christelike gemeenskap omvat. 